\title{
Investigation of Metallo Beta Lactamases and Oxacilinases in Carbapenem Resistant Acinetobacter baumannii Strains Isolated from Inpatients
}

\author{
M. Duygu Aksoy ${ }^{1}$, Şaban Çavuşlu², H. Murat Tuğrul ${ }^{2}$ \\ ${ }^{1}$ Yozgat Public Health Laboratory, Yozgat, Turkey \\ ${ }^{2}$ Department of Medical Microbiology, Trakya University Faculty of Medicine, Edirne, Turkey
}

Background: Resistance to beta-lactam antibiotics is widespread among Acinetobacter strains. Plasmid-mediated metallo beta lactamases (MBL) are responsible for carbapenem resistance, as are oxacillinases (OXA). In recent years, MBL producing carbapenem-resistant strains have been reported in the world and in Turkey in increasing rates. In our country, besides the OXA 51like enzyme which is inherent in A. baumannii strains, OXA 58-like and OXA 23-like carbapenemases producing strains have also been widely detected. In addition, Verona Imipenemase (VIM) and (IMP)-type MBL have been reported in some centers.

Aims: The aim of our study was to investigate the presence of carbapenemases in Acinetobacter strains isolated from hospitalized patients in Edirne.

Study Design: Cross-sectional study.

Methods: A total of 52 imipenem-resistant A. baumannii strains isolated between January and March 2013 were investigated. The presence of MBL was described phenotypically by the combined disk diffusion test (CDDT), double disk synergy test (DDST), MBL Etest (only performed in 28 strains) and modified Hodge test. bla ${ }_{\mathrm{IMP}}$, bla $_{\mathrm{VIM}}, \mathrm{bla}_{\mathrm{GIM}}$, bla $\mathrm{SIM}_{\mathrm{S}}$, bla $\mathrm{SPM}_{\text {genes and }}$ bla $_{\text {OXA-23 }}$, bla $_{\text {OXA-51 }}$, bla ${ }_{\text {OXA-40, }}$, bla ${ }_{\text {OXA-58 }}$ genes were investigated by multiplex polymerase chain reaction (PCR). The blaNDM-1 gene was determined by PCR.

Results: By modified Hodge test, 50 strains (96\%) were found to be MBL positive. Positivity of MBL was $21 \%$ by both CDDT ( $0.1 \mathrm{M}$ EDTA) and DDST. Twenty-four of 28 strains $(85.7 \%)$ were positive by MBL E-test. OXA 23-like and OXA 51-like carbapenemases were detected in all strains, but OXA 58-like and OXA 40-like carbapenemases-producing $A$. baumannii were not detected. Also, MBL genes were not detected by genotypic methods.

Conclusion: Only OXA 23-like carbapenemase was responsible for carbapenem resistance in carbapenemresistant Acinetobacter strains in Edirne. The MBLproducing Acinetobacter strain is not yet a problem in our hospital. MBL resistance was found by phenotyping tests, which must be confirmed by genotypic methods; multiplex PCR tests can be easily used for screening MBL.

Keywords: Acinetobacter baumannii, metallo beta lactamases, oxacillinases
Acinetobacter baumannii strains are non-fermenting aerobic Gram-negative bacteria that play an important role in hospital infections. Difficulties in the treatment and control of this grow- ing threat make this pathogen an important health problem (1). Resistance to beta-lactam antibiotics is widespread among Acinetobacter strains. Plasmid-mediated metallo beta-lactamases

This study was presented as a poster at the $53^{\text {rd }}$ ICAAC Congress, 10-13 September 2013, Denver, Colorado, USA.

Address for Correspondence: Dr. M. Duygu Aksoy, Yozgat Public Health Laboratory, Yozgat, Turkey

Phone: +90 5068072911 e-mail: dr_m.duygu@hotmail.com

Received: 30.12.2013 Accepted: 30.11.2014 • DOI: 10.5152/balkanmedj.2015.15302

Available at www.balkanmedicaljournal.org

Cite this article as:

Aksoy MD, Çavuşlu Ş, Tuğrul HM. Investigation of metallo beta lactamases and oxacilinases in carbapenem resistant acinetobacter baumannii strains isolated from inpatients.

Balkan Med J 2015;32:79-83. 
(MBL) are responsible for carbapenem resistance, as well oxacillinases (OXA). In recent years, MBL producing carbapenemresistant strains have been reported in the world and in Turkey in increasing rates (2). OXA-51-like, OXA-58-like, OXA-23like carbapenemase-producing strains were detected widely (3, 4). Also, in a recent study, it was reported that a small outbreak was caused by $A$. baumannii which produced OXA-72, a member of OXA-24/40-like enzymes in a Turkish hospital (5). Four types of MBL enzymes have been identified in $A$. baumannii isolates including Imipenemase (IMP), Verona Imipenemase (VIM), Seoul Imipenemase (SIM) and New Delhi Metallo betalactamase (NDM)-1-types throughout the World (6). VIM, IMP and NDM-1-type MBL enzymes have been reported in some centers in Turkey (7-10). In this study, the presence of carbapenemases was investigated by phenotypic methods and the responsible resistance genes were investigated by polymerase chain reaction (PCR) and multiplex PCR in Acinetobacter strains, isolated from hospitalized patients in Edirne.

\section{MATERIALS AND METHODS}

\section{Strain selection}

Between January and March 2013, a total of 52 imipenemresistant A. baumannii strains were isolated from clinical samples (endotracheal aspirates, sputum, blood, urine, intravenous catheter, aspirate, wound, tissue, and cerebrospinal fluid) of different patients. Identification and antibiotic susceptibility analysis of the strains were performed by VITEK 2 system (bioMerieux, Marcy l'Etoile, France). Strains were stored at $-80^{\circ} \mathrm{C}$ until the other tests were performed. $P$. aeruginosa ATCC 27853 was used as a negative control strain. MBL-producing $P$. aeruginosa and carbapenemase-producing $A$. baumannii were used as positive control strains. The positive control strains with a known content of carbapenemases OXA, MBL enzymes) were provided from the Department of Microbiology, Istanbul Faculty of Medicine, İstanbul University in Turkey.

Phenotypic determination of carbapenemase production

The presence of MBL was described phenotypically by the combined disk diffusion test (CDDT) with $0.1 \mathrm{M}$ and $0.5 \mathrm{M}$ ethylenediamine-tetraacetic acid (EDTA), double disk synergy test (DDST), and MBL E-test (only performed in 28 strains) and the presence of all carbapenemases was described by the modified Hodge test (MHT).

Combined disk diffusion test: Imipenem (10 mg) disks, imipenem/0.1 M EDTA and imipenem/0.5M EDTA combined disks were used for screening. Increases of $\geq 4 \mathrm{~mm}$ in the zone diameters of imipenem disks in the presence of 0.1 M EDTA and Increases of $\geq 7 \mathrm{~mm}$ in the zone diameters of imipenem disks in the presence of $0.5 \mathrm{M}$ EDTA were interpreted as a possible MBL positivity (11).

Double disk synergy test: Imipenem disks were placed 20 $\mathrm{mm}$ (center to center) away from the blank disk. Then, $10 \mathrm{~mL}$ of $0.5 \mathrm{M}$ EDTA were added on the blank disk. Zone enhancement between two disks was evaluated positive for MBL (12).

MBL E-test: The MBL E-test strip (bioMerieux, Solna, Sweden) containing a double sided of Imipenem (4 to $256 \mu \mathrm{g}$ / $\mathrm{ml}$ ) and Imipenem (1 to $64 \mu \mathrm{g} / \mathrm{ml}$ ) in combination with a fixed concentration of EDTA was used for MBL detection. It was evaluated according to the instructions. MIC ratio of $\geq 8$ for the 2 reagent sides of imipenem and imipenem with EDTA was indicative MBL production This test was only performed in 28 strains (13).

Modified Hodge test: A 0.5 McFarland dilution of Escherichia coli ATCC 25922 was prepared. A 1:10 dilution was streaked as a lawn onto a Mueller Hinton Agar (MHA) plate (Merck, Darmstadt, Germany) and a $10 \mu \mathrm{g}$ imipenem disk was placed in the center of the plate. A. baumannii strains were streaked in a straight line from the edge of the disk to the edge of the plate. After 24 hours, if test organisms had carbapenemases, the test showed a cloverleaf-like indentation of the $E$. coli growing along the test organism growth streak within the disk diffusion zone (12).

Genotypic determination of carbapenemase production

Strains selected for gene detection were inoculated onto MHA at $37^{\circ} \mathrm{C}$ for 18 hours. One colony from this fresh culture was resuspended in $200 \mu \mathrm{L}$ of sterile water and heated at $95^{\circ} \mathrm{C}$ for 10 minutes. This was followed by centrifugation at $13,000 \times \mathrm{g}$ for 10 minutes. The obtained supernatant was served for PCR using the Thermocycler (iCycler iQ Real Time PCR, Minnesota, USA) with the specific primers shown in Table 1.

Responsible resistance genes were investigated by PCR and multiplex PCR in Acinetobacter strains. The bla $a_{\mathrm{IMP}-\mathrm{like}}, b l a_{\mathrm{VIM}-}$ like, $b l a_{\mathrm{GIM}-1}, b l a_{\mathrm{SIM}-1}, b l a_{\mathrm{SPM}-1}$ genes and bla ${ }_{\mathrm{OXA}-23,}$, $l a_{\mathrm{OXA}-51,}$ blaOXA-40, bla ${ }_{\text {OXA-58 }}$ genes were investigated by multiplex PCR $(14,15)$; these PCRs were run as two separate tubes. The bla $_{\mathrm{NDM}-1}$ gene was determined by individual PCR (16).

The final $50 \mu \mathrm{L}$ PCR mixture contained 10x PCR buffer (10 $\mu \mathrm{L}), 2 \mathrm{mM}$ deoxynucleoside triphosphates (dNTP) $(10 \mu \mathrm{L})$, $2.5 \mathrm{mM} \mathrm{MgCI}_{2}(5 \mu \mathrm{L})$, each of the forward and reverse primers $(1 \mu \mathrm{L}), 1 \mathrm{U}$ Taq DNA polymerase $(2 \mu \mathrm{L})$ and genomic DNA of the test strain $(2 \mu \mathrm{L})$. Thermal cycling was programmed for multiplex PCR at $94^{\circ} \mathrm{C}$ for $5 \mathrm{~min}$, followed by 30 cycles of amplification. Each cycle consisted of $94^{\circ} \mathrm{C}$ for $25 \mathrm{~s}, 52^{\circ} \mathrm{C}$ for $40 \mathrm{~s}$, and $72^{\circ} \mathrm{C}$ for $50 \mathrm{~s}$. A final extension step $\left(72^{\circ} \mathrm{C}\right.$ for 6 min) completed the amplification (15). Then, single NDM-1 
TABLE 1. The primers of target genes used for PCR

\begin{tabular}{|c|c|c|c|}
\hline Primer & Sequence $\left(5^{\prime}-3^{\prime}\right)$ & Product size (bp) & Reference \\
\hline$B l a_{\mathrm{IMP}}-\mathrm{F}$ & 5'-GGAATAGAGTGGCTTAATTCTC & (188 bp) & \\
\hline$B l a_{\mathrm{IMP}}-\mathrm{R}$ & 5'-CCAAACCACTACGTTATCT & & \\
\hline$B l a_{\mathrm{SPM}-1}-\mathrm{F}$ & 5'-AAAATCTGGGTACGCAAACG & (271 bp) & \\
\hline$B l a_{\mathrm{SPM}-1}-\mathrm{R}$ & 5'-ACATTATCCGCTGGAACAGG & & \\
\hline$B l a_{\mathrm{VIM}^{-}}-\mathrm{F}$ & 5'-GATGGTGTTTGGTCGCATA & $(390 \mathrm{bp})$ & \\
\hline$B l a_{\mathrm{VIM}}-\mathrm{R}$ & 5'-CGAATGCGCAGCACCAG & & \\
\hline$B l a_{\mathrm{GIM}}-1-\mathrm{F}$ & 5'-TCGACACACCTTGGTCTGAA & (477 bp) & \\
\hline$B l a_{\mathrm{GIM}}-1-\mathrm{R}$ & 5'-AACTTCCAACTTTGCCATGC & & \\
\hline$B l a_{\mathrm{SIM}^{-1}}-1-\mathrm{F}$ & 5'-TACAAGGGATTCGGCATCG & $(570 \mathrm{bp})$ & Ellington et al. 2007 Woodford 2010 \\
\hline$B l a_{\mathrm{SIM}^{-1}}-\mathrm{R}$ & 5'-TAATGGCCTGTTCCCATGTG & & \\
\hline$B l a_{\text {OXA-51 }}-\mathrm{F}$ & 5'-TAA TGC TTT GAT CGG CCT TG & (353 bp) & \\
\hline$B l a_{\text {OXA-51 }}-\mathrm{R}$ & 5'-TGG ATT GCA CTT CAT CTT GG & & \\
\hline$B l a_{\mathrm{OXA}-23}-\mathrm{F}$ & 5'-GAT CGG ATT GGA GAA CCA GA & $(501 \mathrm{bp})$ & \\
\hline$B l a_{\text {OXA-23 }}-\mathrm{R}$ & 5'-ATT TCT GAC CGC ATT TCC AT & & \\
\hline$B l a_{\text {OXA-40 }}-\mathrm{F}$ & 5'-GGT TAG TTG GCC CCC TTA AA & $(246 \mathrm{bp})$ & \\
\hline$B l a_{\text {OXA-40 }}-\mathrm{R}$ & 5'-AGT TGA GCG AAA AGG GGA TT & & \\
\hline$B l a_{\text {OXA- } 58}-\mathrm{F}$ & 5'-AAG TAT TGG GGC TTG TGC TG & (599 bp) & \\
\hline$B l a_{\text {OXA-58 }}-\mathrm{R}$ & 5'-CCC CTC TGC GCT CTA CAT AC & & \\
\hline$B l a_{\mathrm{NDM}-1}-\mathrm{F}$ & 5'-ACC GCC TGG ACC GAT GAC CA & (264 bp) & Zarfel et al. 2011 \\
\hline$B l a_{\mathrm{NDM}-1}-\mathrm{R}$ & 5'-GCC AAA GTT GGG CGC GGT TG & & \\
\hline
\end{tabular}

PCR at $94^{\circ} \mathrm{C}$ for 5 min was programmed, followed by 35 cycles of amplification. Each cycle consisted of $95^{\circ} \mathrm{C}$ for $30 \mathrm{~s}, 58^{\circ} \mathrm{C}$ for $30 \mathrm{~s}, 72^{\circ} \mathrm{C}$ for $30 \mathrm{~s}$. A final extension step $\left(72^{\circ} \mathrm{C}\right.$ for $\left.10 \mathrm{~min}\right)$ completed the amplification (16). PCR products were analyzed by electrophoresis in a $2 \%$ agarose gel containing $0.5 \mathrm{mg} / \mathrm{L}$ ethidium bromide at $100 \mathrm{~V}$ for 60 minutes and compared with the 100 bp DNA Ladder (Fermentas, St. Leon-Rot, Germany).

\section{RESULTS}

A total of 52 carbapenem-resistant $A$. baumannii strains were investigated. These strains had been collected from intensive care units (ICUs) (62\%), internal medicine clinics $(23 \%)$ and surgical clinics $(15 \%)$. Most of the 52 strains of A. baumannii were isolated from respiratory samples (endotracheal aspirates, sputum) (54\%). 50 strains (96\%) were detected as carbapenemase positive by the modified Hodge test. Positivity of MBL was found to be $21 \%, 21 \%$ and $98 \%$ by CDDT (0.1 M EDTA), DDST and CDDT (0.5 M EDTA), respectively. In total, 24 of 28 strains $(85.7 \%)$ were found to be MBL positive by the E-test. OXA 23-like (100\%) and OXA 51 -like $(100 \%)$ carbapenemases were detected in all strains, but OXA 58-like and OXA 40-like carbapenemases producing A. baumannii were not detected (Figure 1). Also, MBL genes were not detected by genotypic methods (Table 2).
Acinetobacter baumannii is an important opportunistic bacterial pathogen responsible for serious infections. They are predominant pathogens in ICUs in Turkey (17). In this study, most of the 52 strains of $A$. baumannii were collected from ICUs $(62 \%)$. Carbapenem resistance was investigated by phenotypic and genotypic tests of the strains. Although some A. baumannii strains were found to be MBL positive by phenotypic tests which were established for EDTA-susceptible and EDTA-non-susceptible strains, MBL resistance genes were not detected. There was a discrepancy between the phenotypic and genotypic results. It was thought that the EDTA might be responsible for the false MBL positivity in phenotypic tests. Other studies have revealed that the membrane permeabilizing effect of EDTA can increase the susceptibility of Gram-negative bacteria such as A. baumannii, $P$. aeruginosa $(18,19)$. In our country, although Aktaş and Kayacan (11) detected some Pseudomonas and Acinetobacter strains to be MBL-positive by phenotypic tests, no isolate was found to be positive for the presence of $b l a_{\mathrm{IMP}}$ or $b l a_{\mathrm{VIM}}$ genes. Different studies have reported positive results by MBL phenotypic tests, but MBL resistance genes that are common in our country could not be identified in Acinetobacter strains (20-22). Rodrigues et al. (23) reported that the phenotypic test to detect 


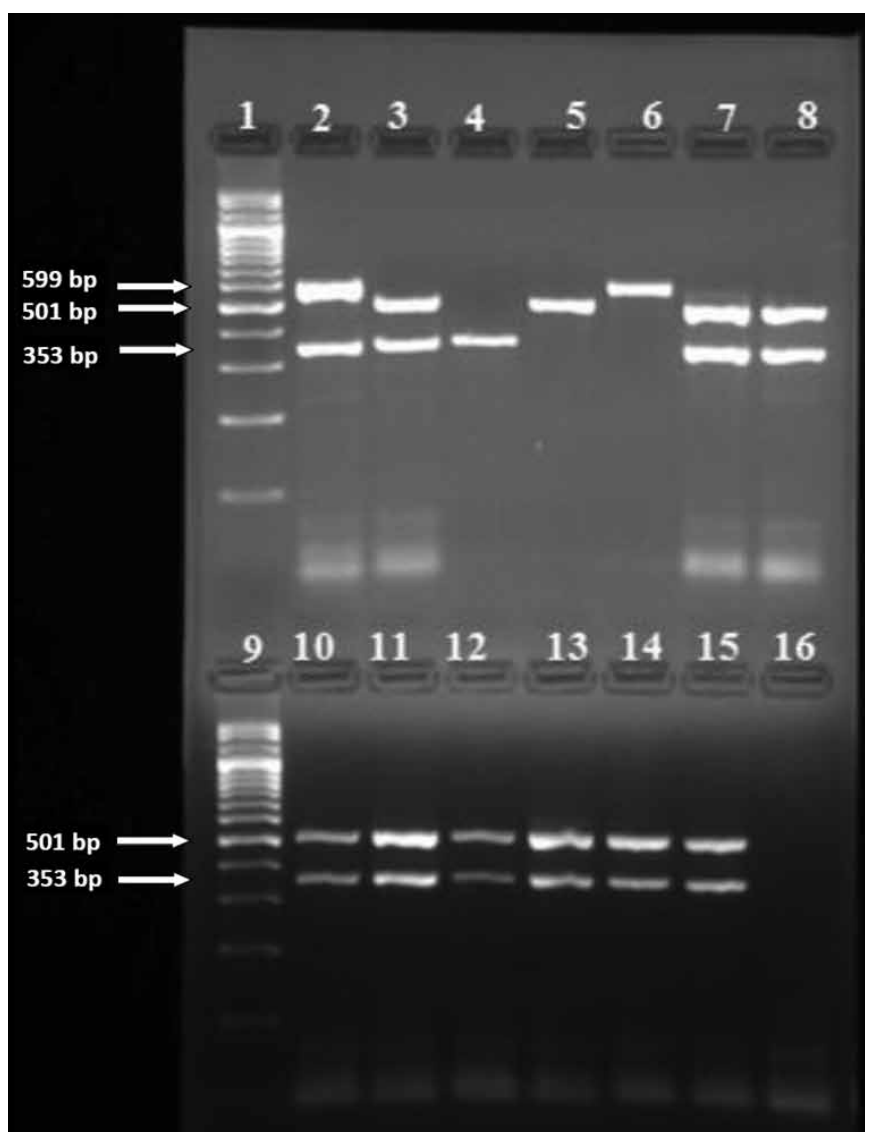

FIG. 1. Multiplex PCR gel showing of bla ${ }_{\mathrm{OXA}-23}$ and $b / a_{\mathrm{OXA}-51}$ positive Acinetobacter strains 1, 9: ladder (100bp); 2-6: positive controls (2: OXA-51, 58; 3: OXA-51, 23; 4: OXA-51; 5: OXA-23; 6: OXA-58), 7-15: clinical samples, 16: negative control

MBL was positive in 5\% (2/40) of $P$. aeruginosa isolates; however, none of the investigated genes $\left(b l a_{\mathrm{IMP}}, b l a_{\mathrm{VIM}}, b l a_{\mathrm{SPM}}\right)$ were identified by PCR. Ratkai et al. (24) reported that most $P$. aeruginosa strains were found to be MBL-positive by the MBL E test and combined disk test, but no MBL genes were detected. Chu et al. (25) reported false positive results in P. aeruginosa strains by MBL E-test and disk synergy methods using EDTA. MBL genes were not detected by PCR. As can be seen from the studies, carbapenem resistance genes, which are common in the region, should be investigated to evaluate the phenotypic test results correctly.

Although MBL resistance genes were not detected, other than the $b l a_{\mathrm{OXA}-51}$ gene which is isolated in A. baumannii strains, the $b l a_{\mathrm{OXA}-23}$ gene, which seems to responsible for the carbapenem resistance in Edirne, was detected in all of the strains tested in our study. These carbapenemases are particularly widespread in our country. OXA-23-like, OXA-51like, OXA-58-like, OXA-24/40-like enzyme-producing $A$. baumannii strains were previously reported in Turkey (3-5, 26, 27). In Greece, Pournaras et al. (28) reported that OXA51-like and OXA-58-like enzyme-producing A. baumannii
TABLE 2. Positivity and negativity rates of MBL by phenotypic and genotypic tests

\begin{tabular}{lcc}
\hline & \multicolumn{2}{c}{ Acinetobacter baumannii $(\mathrm{n}=52)$} \\
\cline { 2 - 3 } Phenotypic tests & MBL $(+) \mathrm{n}(\%)$ & MBL $(-) \mathrm{n}(\%)$ \\
\hline CDDT & $11(21.1)$ & $41(78.8)$ \\
IPM + 0.1 M EDTA & $51(98)$ & $1(1.9)$ \\
IPM + 0.5 M EDTA & $11(21.1)$ & $41(78.8)$ \\
DDST & $50(96)$ & $2(3.8)$ \\
MHT & $24(85.7)$ & $4(14.2)$ \\
MBL E Test & & \\
Genotypic tests & 0 & 52 \\
MBL PCR & 52 & 0 \\
OXA PCR &
\end{tabular}

MBL: metallo beta-lactamase; CDDT: combined disk diffusion test; EDTA: ethylenediamine-tetraacetic acid; DDST: double disk synergy test; MHT: modified hodge test; OXA: oxacillinase, PCR: polymerase chain reaction

strains were detected, but MBL genes $\left(b l a_{\mathrm{IMP}}, b l a_{\mathrm{VIM}}, b l a_{\mathrm{SIM}}\right.$, $b l a_{\text {SPM }}$ genes) were not detected by PCR. In 2010-2011, Liakopoulos et al. (29) reported that OXA-23-like and OXA-58like carbapenemases were detected in carbapenem-resistant A. baumannii isolates. Strateva et al. (30) reported OXA-23-like carbapenemase in multidrug-resistant $A$. baumannii isolates in a Bulgarian university hospital. Although OXA 58-like and OXA24/40-like carbapenemases have been reported in neighboring countries and in Turkey, they were not detected in Edirne.

As a conclusion, this study showed that only OXA 23-like carbapenemase was responsible for carbapenem resistance in carbapenem-resistant Acinetobacter strains in Edirne. MBLproducing Acinetobacter strains are not currently a problem in our hospital. MBL resistance found by phenotyping tests must be confirmed by genotypic methods; multiplex PCR tests can be easily used for screening MBL.

\section{Ethics Committee Approval: N/A.}

\section{Informed Consent: N/A.}

Peer-review: Externally peer-reviewed.

Author contributions: Concept - M.D.A., H.M.T.; Design M.D.A.; Supervision - Ş.Ç., H.M.T.; Resource - M.D.A, H.M.T.; Materials - M.D.A.; Data Collection\&/or Processing - M.D.A, H.M.T.; Analysis\&/or Interpretation - M.D.A.; Literature Search - M.D.A, Ş.Ç.; Writing - M.D.A.; Critical Reviews - Ş.Ç., H.M.T.

Acknowledgements: We thank Zerrin Aktaş from the Department of Microbiology, Istanbul Faculty of Medicine, Istanbul University in Turkey for granting the VIM-1, VIM-2, IMP-1, SPM-1, NDM-1, OXA-23, OXA-51, OXA-58 positive strains.

Conflict of Interest: No conflict of interest was declared by the authors. 
Financial Disclosure: The authors declared that this study has received no financial support.

\section{REFERENCES}

1. Giamarellou H, Antoniadou A, Kanellakopoulou K. Acinetobacter baumannii: a universal threat to public health? Int $J$ Antimicrob Agents 2008;32:106-19. [CrossRef]

2. Cornaglia G, Giamarellou H, Rossolini GM. Metallo- $\beta$ lactamases: a last frontier for $\beta$-lactams? Lancet Infect Dis 2011;11:381-93. [CrossRef]

3. Gur D, Korten V, Unal S, Deshpande LM, Castanheira M. Increasing carbapenem resistance due to the clonal dissemination of oxacillinase (OXA-23 and OXA-58)-producing Acinetobacter baumannii: report from the Turkish SENTRY Program sites. J Med Microbiol 2008;57:1529-32. [CrossRef]

4. Vahaboglu H, Budak F, Kasap M, Gacar G, Torol S, Karadenizli A, et al. High prevalence of OXA-51-type class D betalactamases among ceftazidime-resistant clinical isolates of Acinetobacter spp.: co-existence with OXA-58 in multiple centres. $J$ Antimicrob Chemother 2006;58:537-42. [CrossRef]

5. Sarı AN, Biçmen M, Gülay Z. The First Report on the Outbreak of OXA-24/40-Like Carbapenemase-Producing Acinetobacter baumannii in Turkey. Jpn J Infect Dis 2013;66:439-42.

6. Zarrilli R, Pournaras S, Giannouli M, Tsakris A. Global evolution of multidrug resistant Acinetobacter baumannii clonal lineages. Int J Antimicrob Agents 2013;41:11-9. [CrossRef]

7. Bahar G, Mazzariol R, Koncan R, Mert A, Fontana R, Rossolini GM, et al. Detection of VIM-5 metallo-betalactamase in a Pseudomonas aeruginosa clinical isolate from Turkey. $J$ Antimicrob Chemother 2004;54:282-3. [CrossRef]

8. Ozgumus OB, Caylan R, Tosun I, Sandalli C, Aydin K, Koksal I. Molecular epidemiology of clinical Pseudomonas aeruginosa isolates carrying IMP-1 metallo-beta-lactamase gene in a University Hospital in Turkey. Microb Drug Resist 2007;13:191-8. [CrossRef]

9. Yakupogullari Y, Poirel L, Bernabeu S, Kizirgil A, Nordmann P. Multidrug-resistant Pseudomonas aeruginosa isolate co-expressing extended- spectrum beta-lactamase PER-1 and metallo-beta-lactamase VIM2 from Turkey. J Antimicrob Chemother 2008;61:221-2. [CrossRef]

10. Alp E, Perçin D, Colakoğlu S, Durmaz S, Kürkcü CA, Ekincioğlu $\mathrm{P}$, et al. Moleculacharacterization of carbapenem-resistant Klebsiella pneumoniae in a tertiary university hospital in Turkey. $J$ Hosp Infect 2013;84:178-80. [CrossRef]

11. Aktaş Z, Kayacan CB. Investigation of metallo-beta-lactamase producing strains of Pseudomonas aeruginosa and Acinetobacter baumannii by E-test, disk synergy and PCR. Scand J Infect Dis 2008;40:320-5. [CrossRef]

12. Lee K, Chong Y, Shin HB, Kim YA, Yong D, Yum JH. Modified Hodge and EDTA-disk synergy tests to screenmetallo- $\beta$ lactamase-producing strains of Pseudomonas and Acinetobacter species. Clin Microbiol Infect 2001;7:88-91. [CrossRef]

13. Franco MR, Caiaffa-Filho HH, Burattini MN, Rossi F. Metallobetalactamases among imipenem-resistant Pseudomonas aeruginosa in a Brazilian university hospital. Clinics (Sao Paulo) 2010;65:825-9. [CrossRef]

14. Ellington MJ, Kistler J, Livermore DM, Woodford N. Multiplex PCR for rapid detection of genes encoding acquired metallo-betalactamases. J Antimicrob Chemother 2007;59:321-2. [CrossRef]

15. Woodford N. Rapid Characterization of $\beta$ lactamases by Multiplex PCR. In: Gillespie SH. and McHugh TD, editors. Antibi- otic Resistance Protocols. $2^{\text {th }}$ ed. London: Humana Press; 2010. p.181-92. [CrossRef]

16. Zarfel G, Hoenigl M, Leitner E, Salzer HJ, Feierl G, Masoud L, et al. Emergence of New Delhi metallo- $\beta$-lactamase, Austria. Emerg Infect Dis 2011;17:129-30. [CrossRef]

17. Esen S, Leblebicioglu H. Prevalence of nosocomial infections at intensive care units in Turkey: a multicentre 1-day point prevalence study. Scand J Infect Dis 2004;36:144-8. [CrossRef]

18. Ayres HM, Furr JR, Russell AD. Effect of permeabilizers on antibiotic sensitivity of Pseudomonas aeruginosa. Lett Appl Microbiol 1999;28:13-6. [CrossRef]

19. Denny B, West P, Panigrahi D. Effects of permeabilizers on antimicrobial susceptibility of Stenotrophomonas maltophilia and Acinetobacter spp. J Microbiol Immunol Infect 2003;36:72-6.

20. Ulusoy Al M, Mumcuoğlu İ, Aksu N, Dolapçı İ, Karahan ZC, Baran I, ve ark. İmipenem dirençli Acinetobacter İzolatlarında metallo-beta-laktamaz üretiminin fenotipik ve genotipik yöntemlerle araştırılması. Türk Mikrobiyol Cem Derg 2011;41:29-36.

21. Eser ÖK, Ergin A, Hasçelik G. Erişkin hastalardan izole edilen Acinetobacter türlerinde antimikrobiyal direnç ve metallo-betalaktamaz varlığı. Mikrobiyol Bul 2009;43:383-90.

22. Türk Dağı H, Kuş H, Keyik Ş, Arslan U, Tuncer İ, Fındık D. Karbapenemlere Dirençli Acinetobacter baumannii Suşlarında Metallo-Beta-Laktamaz Varlığının Araştırılması. ANKEM Derg 2012;26:187-92.

23. Rodrigues AC, Chang MR, Nóbrega GD, Rodrigues MS, Carvalho NC, Gomes BG, et al. Metallo- $\beta$-lactamase and genetic diversity of Pseudomonas aeruginosa in intensive care units in Campo Grande, MS, Brazil. Braz J Infect Dis 2011;15:195-9. [CrossRef]

24. Ratkai C, Quinteira S, Grosso F, Monteiro N, Nagy E, Peixe L. Controlling for false positives: interpreting MBL Etest and MBL combined disc test for the detection of metallo-beta-lactamases. J Antimicrob Chemother 2009;64:657-8. [CrossRef]

25. Chu YW, Cheung TK, Ngan JY, Kam KM. EDTA susceptibility leading to false detection of metallo-b-lactamase in Pseudomonas aeruginosa by E-test and an imipenem-EDTA disk method. Int J Antimicrob Agents 2005;26:340-1. [CrossRef]

26. Kulah C, Mooij MJ, Comert F, Aktas E, Celebi G, Ozlu N, et al. Characterisation of carbapenem-resistant Acinetobacter baumannii outbreak strains producing OXA-58 in Turkey. Int J Antimicrob Agents 2010;36:114-8. [CrossRef]

27. Ozen N, Ergani A, Naas T, Ogunc D, Gultekin M, Colak D, et al. Outbreak of carbapenem-resistant Acinetobacter baumannii producing the carbapenemase OXA-58 in Turkey. Open Antimicrob Agents J 2009;1:1-8. [CrossRef]

28. Pournaras S, Markogiannakis A, Ikonomidis A, Kondyli L, Bethimouti K, Maniatis A, et al. Outbreak of multiple clones of imipenem-resistant Acinetobacter baumannii isolates expressing OXA-58 carbapenemase in an intensive care unit. J Antimicrob Chemother 2006;57:557-61. [CrossRef]

29. Liakopoulos A, Miriagou V, Katsifas EA, Karagouni AD, Daikos GL, Tzouvelekis LS, et al. Identification of OXA-23-producing Acinetobacter baumannii in Greece, 2010 to 2011. Euro Surveill 2012;17.

30. Strateva T, Markova B, Marteva-Proevska Y, Ivanova D, Mitov I. Widespread dissemination of multidrug-resistant Acinetobacter baumannii producing OXA-23 carbapenemase and ArmA 16S ribosomal RNA methylase in a Bulgarian university hospital. Braz J Infect Dis 2012;16:307-10. [CrossRef] 